Pectunculus acuticostatus. Pl. X. fig. 13.

Testa suborbicularis, subobliqua, postice subangulata, radiatim multicostata, costis tenuibus, sulcisque angulatis; areâ cardinali bifariam tenuiter sulcatâ, dentibus cardinalibus ad utrumque latus numerosis, confertis.

A small species, distinguished by its subangular form posteriorly, its angular radiating ribs, and its numerous close-set hinge-teeth. It approaches in general form to $\boldsymbol{P}$. Pallium, Reeve.

\title{
Ostrea Haitensis.
}

Testa oblonga, crassa, plicata, plicis paucis (senis ad septenis), magnis, undulatis, subsquamosis, squamis nonnunquam subtubulosis; limbo interno omnino glabro.

This species appears to be related to $O$. imbricata, Lam.; it differs, however, in its general form, which is oblong and not orbicular, and in the number of external radiating folds, which are only six or seven in our shell.

\section{SPONDYLUS BIFRONS.}

Testa subregularis, rotundata, ventricosa, margine latiusculo, valide denticulato; extus radiatim costata, costis 5 ad 6 spiniferis; areâ cardinali alterius valvæ angustissimâ, alterius latiori.

Nearest to S. imperialis, easily distinguishable by the area of one valve being very narrow, and that of the other being rather broader, though still narrow.

\section{Observations on the Silurian Strata of the South-East of Scot-} Land. By James Nicol, F.R.S.E., F.G.S., Assistant-Secretary Geol. Soc.

DuRING a visit to the south of Scotland last autumn I collected some fossils from the older rocks of that district, which appear interesting as adding another link to the chain of evidence by which the true age of these deposits may be ascertained. Taken in connection with the fossils formerly noticed* and with those procured by $\mathrm{Mr}$. Moore in Wigtonshire + , they may be regarded as rendering the Lower Silurian age of one part of these beds almost certain, so that the connection of the rocks and mountain-chains of this portion of Britain with those of other countries may now be so far traced out.

The fossils which Mr. Salter last year kindly determined were chiefly procured from the only bed of limestone known in the Silurian rocks of the south-east of Scotland. My hopes of obtaining better or more characteristic specimens from that locality were disappointed, and not even a single new form was discovered after a careful search. Indeed, the highly crystalline texture of the limestone, probably occasioned by a mass of trap with which it is always assuciated, renders it very improbable that this bed will ever add much to our knowledge of the beings existing in the seas in which it was deposited.

My researches in the slate rocks were more successful, especially in the Grieston quarry near Traquair. In this place the rocks consist of clay-slate, sometimes passing into a fine greywacke, and are wrought

* Quart. Geol. Journ, vol. iv. p. 205. + Jb. vol. v. p. 7. 
for a coarse kind of roofing-slate. The strata are thin and very regular, and dip at $65^{\circ}$ to N. $51^{\circ} \mathrm{W}$. of true direction. No cleavage appears in these beds, and the slates are formed by splitting the mass along the laminæ of deposition, as the position of the fossils clearly proves. The rock is intersected by two sets of open fissures, of which one series dip at $85^{\circ}$ to $\mathrm{W} .45^{\circ} \mathrm{S}$.; and another at the same angle to $\mathrm{E} .5^{\circ} \mathrm{N}$. The amount of dip and the direction vary considerably in both, the second being more irregular; the edges of the beds along it are also broken, rubbed and striated, as if the masses of slate had been pushed over each other. The surfaces of some of the beds are very curiously marked, as the specimens on the table will show. Some of these resemble the ripple-mark common on sandstones, and others are not unlike the impression of some organic body, but the whole are more probably concretionary and entirely mineral in character. In some beds, concretions partly calcareous, partly ferruginous occur, the latter much resembling moss or decaying wood, but showing no trace of organization when examined by the microscope. A few feet above these graptolite beds there is a thin irregular layer from half an inch to two inches thick, of a granular rock containing fragments of steatite and mica of a pinchbeck brown colour.

In this quarry at least two beds containing fossils occur. The upper one is a fine-grained greywacke, the surface of which is almost covered by the Graptolites Sedgwickii, but the specimens, from the nature of the stone, are rarely well-preserved. About ten feet lower a bed of slate has been lately opened containing fossils of this genus in great abundance, which are found not only on the surface, but also through a considerable thickness of the slate. This circumstance, taken in connexion with the finer materials of the matrix and the beautiful state of preservation of the imbedded fossils, shows that these hare lived on the spot, whereas those in the higher bed have more probably been drifted to this place by a stronger current. About seventy to eighty feet higher a third bed containing graptolites is known, but as a slip intervenes, it may probably be one of those already mentioned. At least six species of graptolites occur in this locality, as enumerated in the following list :-

$\begin{array}{ll}\begin{array}{c}\text { Graptolites Sedgwickii, Portlock. } \\ \text { distans, Praptolites convolutus, Hisinger. }\end{array} & \begin{array}{l}\text { Grapto } \\ \text { tenuis, Portlock. }\end{array}\end{array}$

The last seems very distinct from any species formerly described, and is well-characterized by the oblong form of its polyp-cells which are closely appressed to the axis. The first four of these species were found by Colonel Portlock in the Lower Silurian slates of Desertcreat in Tyrone; and the third, G. tenuis, also by Mr. James Hall in the black slates of the Hudson River group of New York, which is considered by Mr. Sharpe and others as the equivalent of the Lower Silurian deposits of England. The G. ludensis, though originally discovered by Sir Roderick Murchison* in a higher part of the series, extends down into the Llandeilo flags. The G. convolutus, first described by Hisinger from the clay-slates of Sweden, has been since

* Silurian System, p. 694, pl. xxvi. figi 1,1 la. 
found in Ireland. These new discoveries therefore form a very satisfactory confirmation of Mr. Salter's identification of the trilobites and shells of the Wrae limestone with those of the Tyrone beds.

The Grieston slates often contain small fragments of anthracite, and a considerable amount of this substance was found some years ago in the Cadon Bank, a hill about a mile distant, forming an irregular bed or vein among the greywacke strata. It is very impure, and burns with much difficulty, so that even after being exposed for some time to the flame of the blowpipe, the form of the mass is little altered. The strata in which it occurs have been much disturbed and affected by igneous action, being intersected in one place by a vein of amygdaloidal greenstone, whilst the top of the hill is formed of red felspar porphyry. In the ashes of this anthracite I have observed tubular fibres under the microscope, so that no doubt can be entertained of its organic nature. It thus proves that plants existed even in these early periods, in sufficient abundance to produce thin beds or seams of coal. In the Grieston slates some markings occur which may have been algæ, but the structure shown in the ashes of the anthracite would rather indicate a higher class of vegetation.

About three miles to the north-east of the Grieston and nearly in the strike of the beds, I also succeeded in obtaining a few specimens of fossils. They were found on Torysknies, a hill belonging to that group, in which, as the map will show, igneous action has chiefly prevailed in this district; the felspar porphyries decreasing in amount with the distance from it. The summit of the hill is formed of porphyry, but the declivities consist of hardened slates, often almost crystalline in texture and closely resembling clinkstone. They contain much iron, and seem so altered by the connected igneous rocks, that the preservation of fossils was very unexpected, and proves the extreme difficulty of destroying organic forms when they are once imbedded in the solid stone.

The discovery of these remains in the prolongation of the former strata, shows that the fossiliferous beds are probably persistent for considerable distances, and may thus aid us in working out the succession of these accumulations. It was also interesting on another account. About 500 yards south of the Grieston slates, a bed of red felspar porphyry is seen running nearly parallel to the slates, and may be traced in the same position relative to their outcrop for about a mile westward. A similar rock occurs at intervals for nearly four miles in the same line, but seems to disappear with all the rocks of this class before reaching the valley of the Yarrow. On the east I have traced this, or a similar vein, at short intervals, cropping out on the sides of the hills or in the beds of the streams to a point north of that where the graptolites occur : at this place, however, the vein appears to have divided into two beds about fifty yards apart. This vein seems thus continuous for nearly eight miles in one direction, and runs generally parallel to the strata. This parallelism is, however, not complete, as it is in one place to the south, in the other to the north of the fossiliferous beds, and has therefore intersected them in the interval*.

* A still stronger proof that some at least of these felspar rocks are not contemporaneous with the strata, but truly injected masses or dykes, is furnished by 
In Thornielee slate quarry in Selkirkshire, on the bank of the Tweed, about six miles below Grieston, a few specimens of two of the same species of graptolites were found. The beds here dip at $82^{\circ}$ to $\mathrm{S} .50^{\circ}$ E., or in the opposite direction to those at the former place, and also lie considerably south of their strike, so that they may thus form merely the other side of an anticlinal axis. 'They have, however, a different mineralogical aspect, being often of a brownish red colour, so that I am more inclined to consider them distinct. Besides the $G$. convolutus and the $G$. ludensis, there is probably a foliaceous species of this genus, which is not seen in the Grieston slates. In the latter also annelid impressions are rare, whereas in Thornielee quarry they are very abundant, thus strengthening the view that these two localities belong to distinct parts of the series. Some of these wormlike impressions much resemble the species figured in the 'Silurian System' of Sir Roderick Murchison, and may even be identical ; but it is difficult to obtain certainty in regard to forms presenting so few well-defined characters, that eren their animal nature may be doubted. The regularity of the folds, with the apparent impression of feet or setæ on the margin, seem to show that they are organic, and rather an impression of the body of the animal itself than a mere trail left in the soft mud*. Similar fossils occur in the Tyrone beds, which, as Colonel Portlock statest, " exhibit on their surfaces those markings like the stems of algæ and the tortuous labyrinths of annelids, so common to indurated muddy or sandy strata." They have also been observed in the older palæozoic rocks of North America, and several, not unlike those from Scotland, are figured by Mr. Emmons from his so-called Taconic group. Thus far they confirm the riew now given of the age and connexion of these rocks; though as similar rude memorials of extinct life occur in formations of every age, they perhaps rather indicate similarity of conditions during deposition than identity of aget.

From the whole facts noticed in this and a former paper, there can be little doubt that the slates and greywackes of this part of Scotland belong to the Lower Silurian period, and are probably the equivalents of the Llandeilo flags of Wales. Judging from the specimens of the older Welsh rocks contained in the Museum of the Society, these

several veins that intersect the strata at a considerable angle. Veins of this kind may be seen in Priesthope, though most of them in that locality conform to the bedding. A vein near the source of the Leithen with a direction to $\mathrm{S} .50^{\circ} \mathrm{E}$. by compass, whilst the strike of the strata is nearly from E. to W., also confirms this view. In a mass of vertical, or nearly vertical strata, the line of least resistance to the escape of an igneous rock would of course be between the beds.

* Some of these impressions penetrate a considerable thickness of the slate, even as much as one-fourth of an inch. This shows that the animal has rather lived in the mud than moved through it. The peculiar arrangement in the mass below might arise from the worm gradually raising its body towards the surface by a kind of undulating motion as the soft mud accumulated and deprived it of access to the water.

+ Geol. Report on Londonderry, p. 230.

$\mp$ Similar forms are common in rocks of the coal formation and the lias, and specimens from both are preserved in the Museum of the Society. Sir Charles Lyell recently presented others from modern mud deposits in the Bay of Fundy. See Quart. Geol. Journ, vol. v. p. 344. 
flags are also the most closely allied in mineral character to the Silurian formations of the region now considered. 'The coarse white siliceous grits common among the Caradoc sandstones are unknown, so far as I have observed, among the old rocks in the south-east of Scotland. The only beds that approximate to these grits in mineral aspect are some in the south of Roxburghshire, and thus in what is probably a newer part of the series (perhaps equivalents of some part of the upper Ludlow rocks?). The most important peculiarity of the Welsh rocks, is the great abundance of organic life which they exhibit when compared with the few traces found in the north. They seem also to differ somewhat in mineral composition, containing a much greater amount of felspathous and apparently volcanic materials than are seen in the Scottish strata. Even mineral and metallic products are, with a few exceptions, rarer in the latter deposits ;-probably consequences or at least indications of a less frequent contemporaneous igneous action. It is an interesting question how far we can connect the more or less abundance of life in these ancient seas with the variety of mineral ingredients thrown into their waters by volcanos existing at the time*.

The Silurian beds discovered by Colonel Portlock in Tyrone, are, however, the nearest equivalents of those now described. The mineral characters of the rocks do not appear very different, and in both countries they are characterized by the comparative scarcity of calcareous matter. The Irish strata also lie in the direct continuation of the northern part of the Scottish mountains, from the termination of which, near Portpatrick, they are only separated by an interval of 100 miles. From Peebles-shire the distance is nearly 200 miles, and the agreement in organic remains is perhaps closer than might have been expected, more especially as not more than three of the Peebles-shire fossils appear among those collected by Mr. Moore in an intermediate locality. It is also worthy of notice, that whilst the Grieston graptolites have only serratures on one side of the axis, those from Wigtonshire generally show these on both sides : hence the latter probably belong to another part of the series, and perhaps correspond with the patch of Silurian schists discovered in Fermanagh in Ireland, which contain the $G$. pristis and other foliaceous species like those in Wigton. These strata lie further south than the Tyrone beds with which the Peeblesshire deposits have most affinity, and Colonel Portlock + also places them in a higher part of the series. In both countries therefore, the older rocks occur on the north, the newer on the south, a coincidence confirming the classification of the Scottish deposits here proposed. In another point, the geological history of the two districts also cor-

* The contemporaneous traps of the English Silurian deposits are described by Sir R. I. Murchison in his great work on this formation. See Silurian System, pp. 75, 269, 401, \&c. ; comp. Journ. Geol. Soc. vol. iii. p. 171-175. In this place the author ascribes the comparative rarity of animal life in certain portions of the English strata, to the intense igneous action which accompanied their deposition. The opposition to the vicw in the text is only apparent, as the eruptions which in their immediate vicinity and during the time of their most violent action were sufficient to destroy life, might yet be favourable to its development during the intervals of repose and at greater distances, by introducing more calcareous and other substances into the water. + Report on Lond p. 232. 
responds. Colonel Portlock draws attention to the strongly marked line of demarcation between the fauna of the ancient rocks in this part of Ireland and that of the formations which succeed them. "In fact," he says, "there is here no such intermediate formation, in a fossil sense, as the Devonian system ; that is, there is no formation in which fossils peculiar to itself are commingled with a large percentage of those belonging to the Silurian on the one hand, and the carboniferous on the other*." And this may with equal truth be asserted of the south of Scotland, where the break both physical and palæontological, between the Silurian and the next higher formation, is remarkably distinct, and indicates a long period during which no deposits have been here formed. It was probably during this interval that the rich ichthyolitic beds of Perthshire, Forfarshire and the north of Scotland were accumulated. It is in the latter localities therefore that a transition downwards from the well-known carboniferous and old red sandstone forms of life into those of the Silurian beds must be sought, rather than on the southern side of the synclinal trought.

Any estimate of the thickness of these Silurian deposits must evidently be very imperfect, as the thick covering of detritus renders it almost impossible to work out continuous sections. The difficulty is increased by the principal rivers flowing generally along the strike of the beds, so that those transverse gorges in which full displays of the stratification might be expected to occur are very rare. The following calculations, therefore, are merely hypothetical, and intended rather to stimulate than to satisfy inquiry. Assuming that the Thornielee slates belong to a different part of the series from those of the Grieston, we have in this part of Scotland three distinct bands of fossiliferous rocks running from south-west to north-east in nearly parallel lines. The most northerly is the Wrae limestone, which, in a country where lime is of so much value, we may well believe would have been known had it again cropped out to the south. It can be certainly traced for more than a mile, having been quarried on the south side of the Tweed near Drumelzier Castle, where it is also accompanied by trap. A similar trap rock is seen twelve miles east in the Eddleston river associated with an impure limestone formerly quarried, which probably forms the continuation of this bed. The distance of these three bands from each other, measured on the map, at right angles to their strike, is six miles from the first to the second, and four miles from the second to the third, or ten miles in all. Allowing for the inclination of the strata, supposed to dip at an average angle of $50^{\circ}$, which is much below the reality, the beds included in these two zones will have a thickness of about 40,000 feet, or of 24,000 feet in the more northern one alone. As this is exclusive of the whole mass of more recent beds on the south, the Silurian formations of Scotland at least equal those of other countries in the amount of accumulations, however inferior they may be in abundance of organic remains.

* Report on Lond. p. 233.

† The "enormous aggregate thickness of the former deposits" was noticed twenty years ago by Prof. Sedgwick and Sir R. I. Murchison. See Trans. Geol. Soc., 2nd Series, vol. iii. p. 141. 
In his Note on the most ancient systems of mountains in Europe*, M. Élie de Beaumont includes the southern mountains of Scotland in his Westmoreland and Hundsrück system, though with some hesitation from uncertainty as to the age of the strata and their mean direction. The former difficulty may now be regarded as removed by the fossils collected by Mr. Moore and myself in such distant parts of the chain, and it thus seems worth while to inquire how far the general direction of the beds coincides with that which he assigns to this system. Among a large number of observations in Peebles-shire and the neighbouring counties, only sixty-six were sufficiently precise to be used for this purpose. With two exceptions, probably accidental, the whole of these fall in an arc of $65^{\circ}$, or little more than one-third the circle. Thirty-five or more than a half dip to the north, thirteen or one-fifth are,vertical, and the remainder, eighteen in number, dip south, as shown in fig. 1, in which the Roman numerals mark the number of beds, when more than one, corresponding to each line. The mean of the whole is E. $35^{\circ} 10^{\prime} \mathrm{N}$., or about $9^{\circ}$ north of the magnetic east. According to M. É. de Beaumont's calculation, the direction of the system, to which he refers this chain, is in this place

Fig. 1.-Direction of Silurian Strata in the South-East of Scotland.

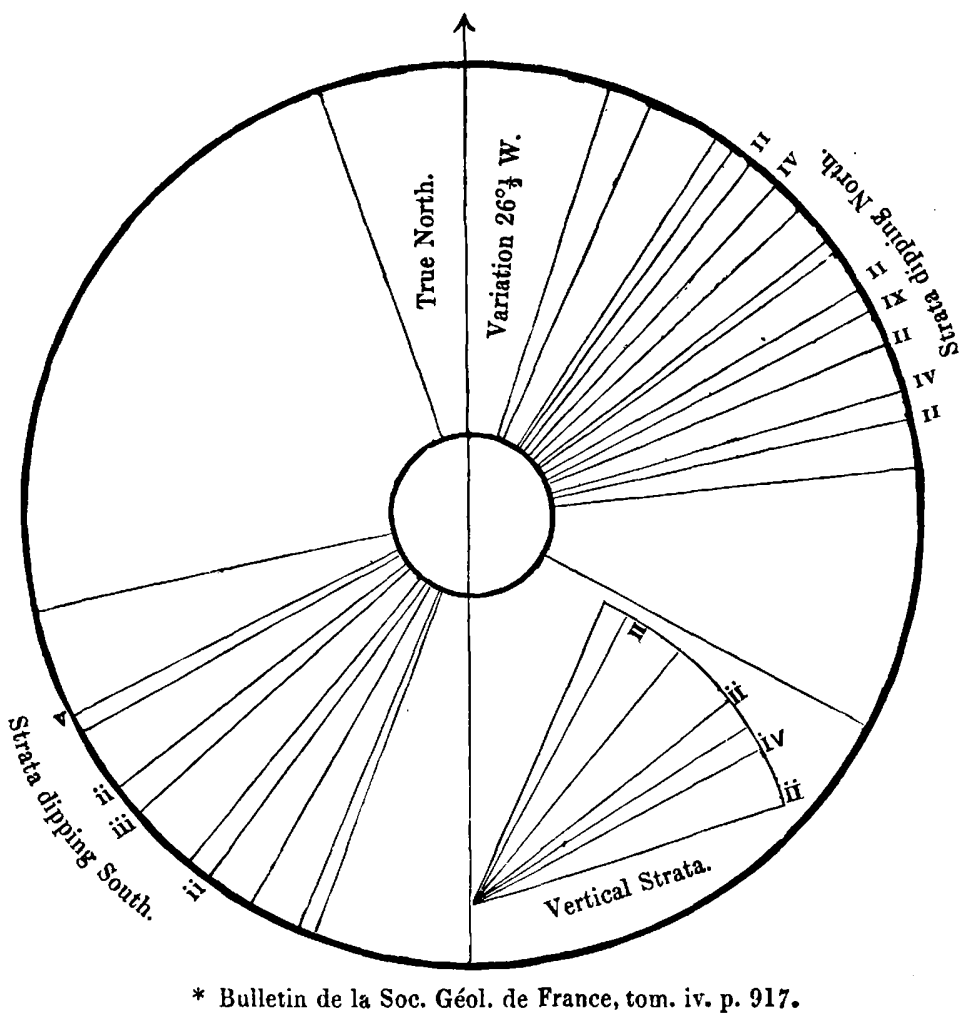


about E. $40^{\circ} \mathrm{N}$., differing $5^{\circ}$ from the mean of the observations. He also ascribes the upheaval of the Grampians to the same great convulsion ; and it is remarkable that the narrow zone of clay-slate, extending from Stonehaven to Arran, has for the greater part of its course a direction of $\mathbf{E} .36^{\circ} \mathrm{N}$., almost identical with the mean of the observations in the south. This band of slate may thus form the continuation of the Silurian beds on the south, rising up on the other side of the synclinal valley in which the carboniferous strata of Scotland have been deposited. The mineral character of the rocks is not opposed to this view; and though no fossils are known in the northern slates, yet in Glen Halmidel in Arran I found spheroidal bodies similar to some very common in Peebles-shire, and which are probably organic, perhaps casts of a species of trilobite.

The direction of these chains is thus not very different from that which the theory would require. The elevation of this system is placed by the distinguished author in the interval between the close of the Silurian and the commencement of the old red sandstone deposits. The latter were formerly* shown to rest unconformably on the edges of the upturned Silurian strata, and also to fill valleys excavated in them subsequent to their elevation. This would carry back the formation of the chain to a period much anterior to the deposition of the sandstone; but as this rock in the south of Scotland should perhaps be rather associated with the carboniferous than with the true Devonian beds of England, an interval of sufficient duration for the various changes, which the strata hare evidently undergone before they were covered up by the superior beds, may thus be obtained.

But although the general direction of the strata and the period of their formation do not differ much from that required, there are other facts in the physical structure of this part of Scotland less favourable to this ingenious theory. The Pentland hills, which have undoubtedly been formed subsequent to the deposition of the old red sandstone, or rather of the coal-measures, have a direction of E. $40^{\circ} \mathrm{N}$., thus agreeing exactly with the line assigned to the Westmoreland system. The same direction is reproduced in many of the ridges in the coal-field of the Lothians, and also in the trap rocks of Fife and the Ochils. In these instances we have parallelism of direction without identity of age. On the other hand, the Cheriots on the south probably coincide in age with the Pentlands, and also in their general direction; but the porphyry rocks constituting their eastern and highest portion form ridges running N.N.E., and thus rary much from the direction of the chain of which they form a chief part, and also from the system of the North of England, with which they should be closely related in time. The structure of this part of Scotland thus confirms the objections to this theory which Sir Henry de la Beche long ago derived from the lines of eleration observed in the south of England + .

* Quart. Journ. Geol. Soc. vol. iv. p. 199.

+ Geol. Manual, 3rd edit. p. 489 . M. E. de Beaumout indeed states that there is a tendency in the older lines of elevation to influence the more recent elevations in their vicinity. This, however, so far from removing the objection, admits its truth, and consequently that parallelism in direction, even in neighbouring mountain-chains, is no proof of identity in the time of their elevation. 
When we contrast the decided unconformity that always appears in Scotland between the Silurian strata and the formations that rest on them, with the perfect parallelism which has been shown to exist*, in the typical region, between deposits of the same age and the overlying old red and carboniferous rocks, the argument becomes still stronger. With such proofs that these ancient disturbances are merely local, and have not affected all the rocks of one age even in the same country or limited district, we can hardly be expected to believe that their influence has extended over the whole of Europe, and even into the more distant regions of Asia and America.

The dip of the strata in this range of mountains is far less regular, either in amount or direction, than their line of strike. On laying down, however, my observations on the map, it appears that towards the northern margin of the Silurian rocks, the dip is generally northwards, whereas as we proceed south a change takes place, and the dip is more frequently to the south. Though there are numerous exceptions, still this fact indicates the occurrence in this part of the chain of an anticlinal axis over which the beds have been folded. Taken generally, this axis will pass from the group of felspar porphyry hills east of Inverleithen to Loch Skene north of Moffat, where igneous rocks also abound. It thus runs along some of the highest mountains south of the Forth; and the mineral springs at the localities just named are probably connected with this line of ancient igneous action. Its general direction is considerably more to the north of east than the average deduced for the strata.

The position of this axis of elevation so near the northern boundary of the Silurian rocks is a point of much interest, from its apparent connexion with some of the most remarkable physical peculiarities of the country. On examining a geological map of Scotland it will be seen that the boundary between the red sandstone and the Silurian formations on the south is very irregular, the newer deposits forming many indentations in the older. It was thence inferred that the red sandstone had been deposited in valleys eroded in the greywacke rocks at a very early period $\dagger$. The northern margin presents a different outline. The border there is for great distances nearly a straight line, with few sinuosities. Thus from the trap hills at the sources of the Nith, the line of junction runs almost direct to Howgate near Pennycuik, where it bends slightly to the south, but soon resumes a rectilinear direction towards the north-east to the coast at Dunglass, where it again curves round to the south. Along this line, especially towards the east, the junction of the two formations is marked by a range of hills composed of highly inclined Silurian strata, against which the red sandstone and carboniferous rocks abut in nearly horizontal beds. In some places this appearance is concealed by the igneous formations, especially those connected with Tinto and the Pentlands, but to the south of Edinburgh and along the base of the Lammermuirs it is very distinctly marked. In many places the close

* See Murchison's Silurian System, chap. xlii. p. 568, \&c., where the inconsistency of this fact with the theory of $M$. $\hat{E}$. de Beaumont is very clearly explained.

+ Journ. of Geol. Soc. vol. iv. p. 200. 
resemblance of the steep slope of the greywacke hills to a sea cliff, somewhat softened by degradation in the long lapse of ages, can scarcely be overlooked by the most careless obserrer.

And such, I believe, has been the origin of the peculiar features of this boundary-line. The Silurian strata evidently extend much farther north below the more recent deposits than their boundary on the map. This is proved by the fragments, covered unconformably by the old conglomerates and sandstones, which are exposed at several points in the Pentland hills where the deeper masses have been forced up by the igneous rocks in that chain. Such an extension of the Silurian beds is also required to balance, as it were, the southern side of the anticlinal arch, stretching down to the border of England. Hence I conclude, that whilst the southern half of the greywacke rocks was being cut into valleys by river action, the northern margin was exposed to the wasting influence of an open sea, which has planed down that rocky bed on which the newer formations of the central trough of Scotland have been deposited. It has only been near the conclusion of the Devonian period that conditions were again established in the southern part of the central valley of Scotland* permitting detritus to accumulate round the ancient shores. This accumulation has then gone on continuously during the whole carboniferous period-red sandstones passing gradually into white, these becoming mixed with shales and then with limestones, as the waters freed from the ironperoxide became more favourable to the growth of corals and crinoids. Later the calcareous deposits decrease in abundance, and shales and sandstones alternate with seams of coal. During this period the land must have been alternately above and below water, the upright trees seen in many places having grown during the former; the large trunks, forty feet long or more, exposed in the sandstone quarries near Edinburgh, having been drifted into the basin during the intervals of submergence.

The influence of these ancient revolutions on the actual physical geography of the country, particularly the direction of river drainage, deserves notice. On drawing a line along the watershed of the mountain chain, separating the rivers that flow south from those that reach the sea on the north of the axis, it is seen that the latter are comparatively insignificant. The division-line falls either very near, or even beyond, the northern boundary of the chain and of the Silurian rocks. Many of the streams that rise in the newer formations of the central district intersect the whole mass of older deposits on their way to the sea. Thus the Nith has its source in the coal formation of Ayrshire, within twelve miles of the Firth of Clyde, but turns south and falls into the Solway, after passing through the whole ridge of Silurian mountains, elevated in many points from 2000 to 3000 feet above the sea. Further west, some of the smaller streams, as the Cree and Ken, illustrate the same peculiarity; and on the east, the Lyne and other

* On the north side of this trough or valley, in Perth, Forfar, and Kincardine shires, these deposits have begun much earlier. This is shown by the great extent of the old red sandstone in these counties compared to its limited development in Ayrshire and the Lothians. 
tributaries of the Tweed follow a course apparently no less devious. The Clyde alone pursues an opposite direction, but many physical phænomena show that its upper waters formerly joined the Tweed by the low valley near Biggar, and hence even this exception is of modern date, and consequent on some of the most recent revolutions in this district. Thus almost the entire drainage of this mountain-chain flows to one side, so that all its larger river-basins open out to the south. The greater number too of the most elevated mountain-summits range along the northern margin, whilst on the south there are many low hills and undulating ridges. Hence the southern valleys are wider and blend more gradually with the plains than those on the north, where the streams often flow through narrow ravines, or deep notches, cut, as it were, in the steep wall of rock forming the ancient sea cliff. The Gladhouse south of Edinburgh, the Herriot near Dunglass, and the singular ravine crossed by the Peas Bridge at a height of 123 feet, but in other places 150 feet deep and only 50 broad, are good illustrations of this peculiarity.

The line of coast south of Dunglass, where Hutton, Playfair and Hall found many of the most convincing illustrations of those great principles of physical geology which they laboured to establish, still exhibits many remarkable traces of this old Silurian beach-line. From the rocky promontory of Fast Castle, the coast trends westward in a series of bold cliffs, fenced by large fragments and outlying points of greywacke. Near Fala-bank it bends more to the north, and the red sandstone appears on the shore, dipping north-east at $25^{\circ}$, and folded in flat curves round the projecting masses of nearly vertical Silurian strata that project at intervals. The sandstone apparently retains its original position, the dip being due to deposition on a sloping bottom, and not to elevation ; and hence, in following the beds along the coast, they become more and more nearly horizontal. It is highly interesting to observe the sea gradually washing away the sandstone and exposing the ancient beach on which its waves beat so many ages before.

\section{Notes on the Fossils.}

Graptolites griestoniensis. Fig. 2.

I have given this name to the new species from the locality where it occurs. The characters mentioned above, "the oblong serratures closely appressed to $a$ the stalk," readily distinguish it from any other I have seen described. Each of these serratures has a raised margin dividing it from the axis and from the one that succeeds it upwards. The serratures and axis are about equal in breadth, and together measure $\frac{1}{20}$ inch or under. The length of some fragments is 6 to 8 inches. In fig. $2, a$ is the natural size; $b$, magnified. 
Graptolites convolutus, Hisinger.

In some specimens, probably young, the axis is very narrow compared to the length of the serrations, being little more than a mere line. In other specimens the axis becomes broader and shows a depressed line along the middle. This relative thickening and increase of the axis with age has already been noticed by Geinitz*. In some, perhaps very old varieties of this species, the axis is much less curred, and the serratures much shorter. They form merely a series of very obtuse and wide teeth, scarcely projecting beyond the margin. This may form a distinct species; but the variations evidently produced by age, or from the manner of imbedding in the stone, as seen in different parts of the same specimen, show that much caution is required in such distinctions.

\section{Graptolites ludensis, Murchison.}

The specimens agree very well with the figure given in the 'Silurian System †.' The most important difference is in the more rounded, almost club-shaped form of the ends of the serratures in the fossils from Peebles-shire. This probably arises from the specimens being in a more perfect state of preservation. In some of the larger specimens both of this species and of the G. Sedgwickii, Portlock, the stem near the root is narrow and almost destitute of serratures, but becomes broader and the serratures very distinct as it ascends. Where also the back of the specimen only is exposed, the serratures may be wholly concealed, so that it appears entirely destitute of these appendages, and such a fragment might readily be taken for a new species. Where the opposite side again is turned to the spectator the serratures are pressed flat, and appear like broad lobes divided by narrow depressions, giving the stalk a jointed appearance. Where the back is well-seen, it is marked by a fine groove running along its centre. Some of our specimens are from 10 to 12 inches long, though imperfect at both ends.

\section{Graptolites laxus.}

The foliaceous species from Thornielee, mentioned above, somewhat resembles the G. pristis, Hisinger, but the axis is much narrower, and the serratures longer in proportion to their breadth (or length to breadth rather more than $2: 1$ ). They are also separated by an interval equal to their own width, or even more, a character not seen in any other foliaceous species figured. In this respect it differs so much from the general aspect of the genus, and so closely resembles some plants of the moss-tribe (Hypnum), as to render its real character doubtful. If a true graptolite, it seems undoubtedly a new

* Leonhard and Bronn's Jahrbuch für 1842, p. 701. The G. spiralis of Geinitz seems identical with the $G$. convolutus, Hisinger.

+ Plate 26, figs. 1 and $1 a$. In this work the importance of these fossils, as distinguishing different parts of the Silurian formations, was first made known to geologists. See pp. 206,694. 
species, to which the above name may be given from its most remarkable character.

The true nature of these remains seems still rather uncertain. Schlotheim described them as Orthoceratites, and in his figure a central siphon is represented, and the stem seems composed of distinct cups or joints*. No indication of either of these characters is seen in the most perfect of our specimens, so that we almost doubt whether his fossil belongs to the same class. Other geologists have described them as fucoids. In the 'Silurian System' they are classed as Polyparia, which seems now the opinion generally received. Some of our specimens have left merely a dark, perhaps carbonaceous impression on the slate; others show a cartilaginous or horny texture. In several specimens the slate is discoloured for some distance on each side, and shows minute scales of carbonate of lime, as if the more perishable parts of the animal had extended thus far. It is thus doubtful whether these remains have all belonged to animals of one class; and whether some of them may not rather have been internal organs, than the external axis of a variety of polypifer?

\section{MAY 30, 1849 .}

P. Martin Duncan, Esq., M.D., and J. Lane Oldham, Esq., were elected Fellows of the Society.

The following communication was then read:-

On the Distribution of the Superficial Detritus of the ALPs, as compared with that of Northern Europe. By Sir Roderick Impey Murchison, F.R.S. G.S. L.S., Hon. Mem. R.S. Ed., R.I. Ac., Mem. Imp. Ac. Sc. St. Pet., Corr. Mem. Ac. France, Berlin, Turin, \&c. \&c.

\section{[Abstract.]}

REFerRing to his previous memoir upon the structure of the Alps and the changes which those mountains underwent, the author calls attention to the fact, that as during the formation of the molasse and nagelflue a warmer climate prevailed, so after the upheaval of those rocks an entire change took place, as proved by the uplifted edges of such tertiary accumulations being surmounted by vast masses of horizontally-stratified alluvia, the forms of whose materials testify that they were deposited under water. The warm period, in short, had passed away and the pine had replaced the palm upon the adjacent lands, before a glacier was formed in the Alps or a single erratic block was translated.

Though awarding great praise to the labours of Venetz, Charpentier and Agassiz, which have shed much light on glaciers, and particularly to the work of Forbes for clearly expounding the laws which

VOL. VI. -PART I.

* Petrefactenkunde, Nachtrage, p. 56, tab. 8. fig. 3. 